\title{
A THEORETICAL MODEL FOR DEVELOPING CORE CAPABILITIES FROM AN INTELLECTUAL CAPITAL PERSPECTIVE (PART 2)
}

\author{
MARIUS UNGERER \\ KOOS UYS \\ Dept of Human Resource Management \\ University of Johannesburg
}

\begin{abstract}
One of the basic assumptions associated with the theoretical model as described in this article is that an organisation (a system) can acquire capabilities through intentional strategic and operational initiatives. This intentional capability-building process also implies that the organisation intends to use these capabilities in a constructive way to increase competitive advantage for the firm.
\end{abstract}

\section{OPSOMMING}

Een van die basiese aannames wat geassosieer word met die teoretiese model wat in hierdie artikel beskryf word, is dat 'n organisasie ('n stelsel) vermoëns deur doelgerigte strategiese en operasionele inisiatiewe kan bekom. Hierdie voorgenome vermoë-skeppingsproses, veronderstel ook dat die onderneming daarop ingestel is om hierdie vermoëns op 'n konstruktiewe wyse te benut om die mededingende voordeel van die organisasie te verhoog.

The creation of conducive and attractive conditions for enhancing a firm's capability-building process is central to the theoretical model as described in this article. The key building blocks that create favourable conditions for the development of organisational capabilities from an Intellectual Capital perspective are defined in the theoretical model and consist of the following five constructs:

- A Strategic Architecture that provides guidance on the strategic intent, focus and boundaries of the organisation.

- An Intellectual Capital Framework that creates a basis for a normative, strategic and operational view to stimulate ideas on how to make intellectual capital a practical reality and to utilise these insights in the development of the organisation's core capabilities.

- A Core Capability Framework that reflects the content and processes related to the identification, description, evaluation and assumptions associated with the firm's core capabilities. The Core Capability Framework also facilitates the integration of the concepts "core capabilities" and "intellectual capital".

- An Operationalisation Framework to leverage core capabilities from an Intellectual Capital perspective in a pragmatic way to realise tangible competitive benefits not only from individual capabilities, but also through the conscious collective use of bundles of capabilities.

- A change enablement process that stimulates knowledge flows between the above key constructs of the conceptual model. This creates the basis for cognitive and emotional leverages to increase the potential of an organisation to successfully implement a strategic approach to the management of core capabilities from an Intellectual Capital perspective.

Raising the awareness and capacity of the organisation on the above five constructs creates the basis for an increase in the potential to make positive progress on this strategic journey of discovery to manage the growth of intellectual capital in a holistic way by focusing on core capabilities.

\section{Content of the Theoretical Model (Part two)}

In part one of this two-part series on a theoretical model for the development of core capabilities utilising an intellectual capital view, the key constructs associated with the term "intellectual capital" were described.

Requests for copies should be addressed to: JS Uys, jsu@rau.ac.za
In this second article the other key concepts associated with the conceptual model as well as the relationships between the different constructs, key assumptions, boundaries and propositions associated with the theoretical model are explored.

Identification and Description of Key Constructs (What) The theoretical model consists of the following five key interrelated elements (see figure 1):

- Intellectual Capital Framework.

- Strategic Architecture.

- Organisational Core Capability Framework (Core Capability Architecture).

- Operationalisation Framework for leveraging core capabilities from an Intellectual Capital perspective.

- Change enablement processes.

(See article one for the content elements of the Intellectual Capital Framework)

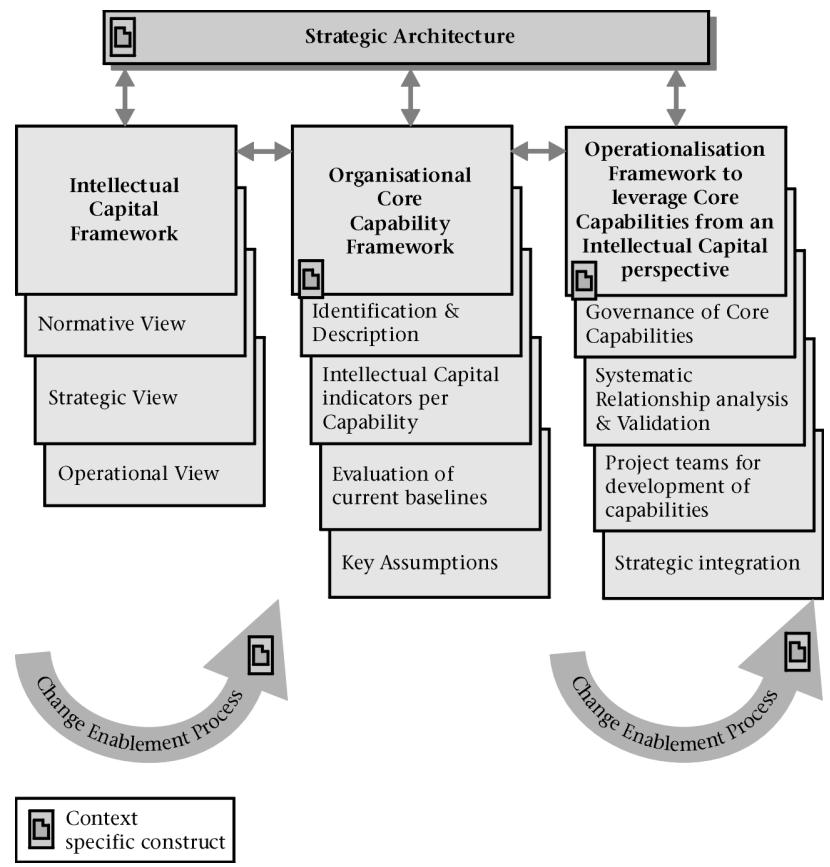

Figure 1: Conceptual Model for the Development of Core Capabilities from an Intellectual Capital perspective. 


\section{Strategic Architecture}

The second core concept of the theoretical model (figure 1) is "Strategic Architecture". This concept is informed from both the literature related to the Dynamic Capability School on strategy and the best practices associated with management of intellectual capital

Elfring and Volberda (2001a: 20) describe the Dynamic Capability School on strategy as: a collective learning process aimed at developing distinctive capabilities that are difficult to imitate. The theory of capability-based competition is rooted in the concepts of "resources", "dynamic capabilities" and "core competence" (Sanchez, 2001). Superior performance is based on developing a competitively distinct set of internal capabilities (what the firm does well) and deploying them with a well-conceived strategy in the competitive environment (what the market demands and what competitors offer). This is the essence of competing on resources and capabilities (Collins \& Montgomery, 1995). Hamel and Prahalad (1994) say that firms will be successful in the future if they focus on the creation of new competitive space for themselves, rather than focusing only on existing competitive opportunities.

Roos and Roos (1997) emphasise that intellectual capital management must be rooted in the strategy (business vision, mission) of the firm. Intellectual capital is a consequence of strategy. Sullivan (2000) indicates that strategic alignment involves focusing the firm's intellectual capital resources on the activities that will mobilise the enterprise towards the realisation of its strategy and vision.

Hamel and Prahalad (1994) introduce the concept of a "strategic architecture" that identifies what we must be doing right now to intercept the future (Hamel \& Prahalad, 1994: 121). They state that a Strategic Architecture aims to achieve the following

- It is the link between today and tomorrow. It strives to link short term actions to long term strategies.

- It indicates what capabilities the firm must begin developing or start to acquire right now to achieve strategic success over time.

- It indicates what customer groups, channels and new developments must be targeted to achieve strategic success.

- It provides the logic for product and market diversification by answering how this contributes to competence building and market dominance.

- It enables decision making about resource allocation priorities. It helps employees to understand the logic of allocation priorities and disciplines senior management to maintain consistency.

The Strategic Architecture of the firm is an approach to a broad plan of opportunity, representing the potential highway to the future. The merits of specific routes only emerge once an organisation has moved forward on this strategy journey.

The Strategic Architecture of a firm identifies and reflects what it must focus on to achieve strategic success. Included in the Strategic Architecture is an indication of the capabilities the organisation requires to ensure the achievement of its strategic intent. The Strategic Architecture of a firm can include the following elements:

- Vision and mission description to highlight what the firm intends to achieve, given a chosen strategic landscape in which it wants to compete. This also gives an indication of the boundaries of the firm's strategic positioning.

- The values of the firm as an indication of the behavioural patterns that are encouraged and supported.

- Core descriptions related to:

- The profit model of the business, answering the question how will we make profit?

- The business model of the business, answering the question how do we organise to make profit?
- The strategic differentiation points the business wants to focus on to leverage key competitive advantages for the firm. The question that drives this view is how do we protect our profit streams?

- The core capabilities the firm utilises for building unique bundles of capabilities to create strategic differentiation in the chosen market space. This answers the question what abilities do we need to achieve our strategic intent?

- The primary mental models that inform the above components of the firm's Strategic Architecture. This answers the question what assumptions do we use as point of depart?

The above elements represent the core dimensions of the Strategic Architecture of a firm and are reflected in figure 2 . The development of this content is context specific and unique for each firm. The content is developed from a Dynamic Capability-Based strategy paradigm where firm-specific resources are utilised to exploit opportunities or to neutralise threats from the external competitive environment (Barney, 1991; Elfring \& Volberda, 2001a; Long \& Vickers-Koch, 1995; Stalk et al., 1992; Teece et al., 1997). The Strategic Architecture creates the context for the next building block, the Core Capability Framework.

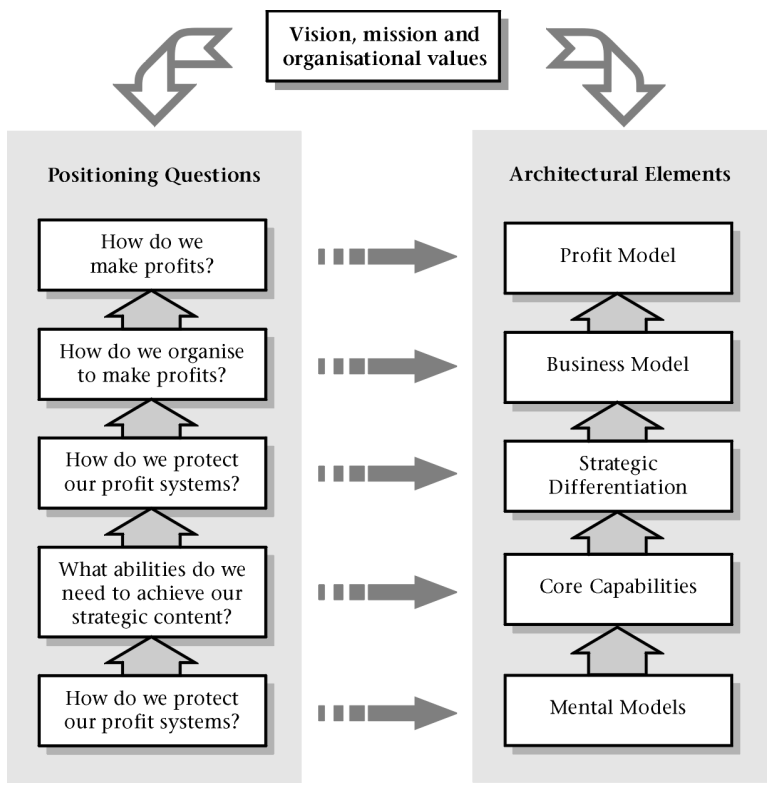

Figure 2: Core elements of a Strategic Architecture

Organisational Core Capability Framework

The third key component of the theoretical model is the "Organisational Core Capability Framework". This relates to the concept core capabilities as described in both the strategic view of the Intellectual Capital Framework and the Strategic Architecture, but expand the shared understanding and meaning associated with the actual content constructs implied in the firm's selected core capabilities.

The core capabilities as identified in the Strategic Architecture of the firm require further clarification and meaning expansion. The Core Capability Framework or Architecture of the firm creates the space to facilitate this meaning creation and sensemaking process. The Core Capability Framework creates a rich shared meaning on the key constructs associated with each chosen core capability and forms a reference point for directing current and future strategic behaviour.

The Capability Architecture represents a flexible, adaptable, and continuously-improving infrastructure of organisational capabilities, which forms the basis for a firm's competitiveness (King, 1995). The Core Capability Framework consists of content 
and processes related to the identification, description and evaluation of core capabilities, as well as key assumptions related to organisational core capabilities. A well-defined strategic Capability Architecture contributes to the enhancement and development of organisational capabilities aimed at the leveraging of competitive benefits for the firm.

The "core" in core capabilities refers to those activities that actually contribute to long-term corporate success and identifies those capabilities that lie at the centre, rather than the periphery, of competitive prosperity (Hamel, 1994). All core capabilities of a firm are not at the same level of maturity (especially in the beginning phases) and represent a mix of well-established capabilities and new capabilities the company requires to be successful. This implies that all the core capabilities will not necessarily pass the criteria of multiple customer value, uniqueness or leveragability (Prahalad \& Hamel, 1990; Hamel, 1994; Hamel, 2000) in the initial stage, but the intent is to develop them to levels where they meet these criteria.

The Core Capability Framework also facilitates the integration of the concepts "core capabilities" and "intellectual capital". The Intellectual Capital perspective on resources is utilised as an intervening variable for expanding the view on the organisation's core capabilities. In this way the core capabilities of a firm are illuminated in a specific way to increase the diversity of perspectives by using multiple lenses, based on the perspectives associated with intellectual capital. This enables a more informed, richer and more expanded view on the capabilities of an organisation. This approach also contributes to a focused development process for core capabilities through the identification of human, structural and customer capital indicators per core capability. This process of utilising the intellectual capital paradigm as a lens for expanding the views on the firm's core capabilities is reflected in figure 3.
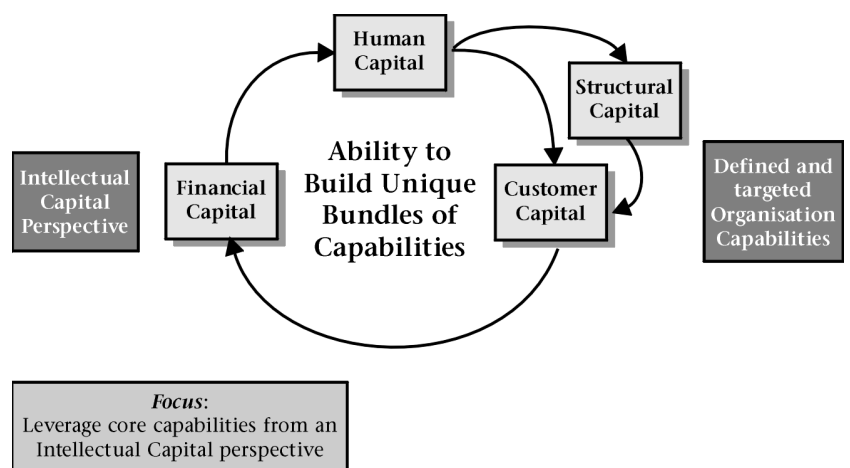

Figure 3: A View on Leveraging Core Capabilities from an Intellectual Capital perspective.

A Core Capability Framework consists of the following key elements:

- A description of key concepts associated with the identified core capabilities. These descriptions should give meaning to the core intent the firm has with each capability and should inform strategic decision-making.

- Intellectual capital indicators per core capability. Human, structural and customer capital indicators are developed from a future ideal position for each identified core capability. This means that these intellectual capital indicators are future orientated and describe an ideal position for each capability in terms of indicators for human, structural and customer capital respectively. The selected core capabilities of the firm, as reflected in the Strategic Architecture, are described in an envisaged end-state format using the three core components of intellectual capital as category holders and applying indicators as a descriptor mechanism.

These intellectual capital indicators per core capability are objects of measurement and are defined in terms that are not as quantifiable (black and white) as normal quantitative measures (Brennan \& Connell, 2000; Harrison \& Sullivan, 2000; Roos et al., 1997). Intellectual capital indicators contribute to knowledge around the question: How will we know over time if we are growing and expanding the creation and contributions of these different core capabilities? Intellectual capital indicators are more qualitatively orientated, but can include specific relevant quantitative indicators. Intellectual capital indicators reflect the position and status of a firm at a specific point in time and are aimed at internal management rather than external stakeholders (Sullivan, 2000).

- The development of a current core capability baseline for the firm to indicate the level of entrenchment. This is achieved through the measurement of the current status in the firm by utilising the intellectual capital indicators per capability. This enables the reflection of current evidence of intellectual capital per capability (or lack of it) against the stated ideal indicators. This information can be utilised in investment prioritisation decisions related to core capabilities and in continuous management of intellectual capital with a focus on growth. This action reflects the measurement part of the Intellectual Capital Framework and can also be combined with other quantitative measurements related to intellectual capital such as single aggregate measures or measures aimed at the individual components of intellectual capital to reflect a variety of relevant measurements (see the approaches of Roos, et al. 1997; Stewart, 1997; Stewart, 2001; Sullivan, 2000).

- A description of the key assumptions associated with the core capabilities of the firm. Assumptions make visible the underlying thoughts associated with the capabilities and represent an additional source of insight and sensemaking. Assumption surfacing is a neutral way to identify prevailing mental models, risks and opportunities associated with the firm's core capabilities. We are not paying enough attention to the irregular, disorderly chance nature of the game. We do this because it is easier and more comfortable than feeling about in the dark for explanations that describe the world in terms of disorder, irregularity, unpredictability and chance (Stacey, 1992: 21).

Operationalisation Framework for leveraging Core Capabilities from an Intellectual Capital perspective

Clarity on the content of the firm's core capabilities, and the expansion of this view by utilising an intellectual capital perspective, create the readiness and energy in an organisation to progress to the next construct in the theoretical model. This represents the operationalisation phase of the development of core capabilities from an intellectual paradigm.

The key content of the Operationalisation Framework for leveraging core capabilities by utilising an intellectual capital view is as follows:

- The development and management of core capabilities is not a once-off project with a start and end date. It is a continuous organisational learning process that requires sponsorship by the leadership in the firm. A governance structure for the on-going management of core capabilities in a firm facilitates this need for involving leadership in a constructive way. A governance structure in the form of an intellectual capital review board, with senior management representation under the leadership of the CEO of the firm, creates the strategic attention and organisational processes for the leveraging of core capabilities from an Intellectual Capital perspective. The key functions of an intellectual capital review board are:

$\circ$ Creating conditions in the firm that are conducive to growing intellectual capital by focusing on core capabilities. Stacey (1992) indicates that new strategic directions emerge from the chaos of challenge and contradictions through a process of real-time learning and interaction. The role of executives is to create favourable 
conditions for, and to participate in these learning interactions. This creates the basis for piecemeal interventions at leverage points in the system.

- Providing the required mandates and resources for the development and maintenance of the firm's core capabilities.

- Providing strategic leadership, direction and focus for the tactical leveraging of core capabilities to improve the strategic differentiation potential of the firm.

- Promoting and communicating the key concepts related to the growth of intellectual capital by focusing on core capabilities to reinforce the message in a visible and vocal way. These messages focus on answering the "why" question and help employees to create their own meaning towards increasing individual self-reference capacity (Wheatley, 1994).

- Reviewing progress related to the entrenchment and leveraging of the firm's core capabilities on a regular basis.

- The Core Capability Framework represents a static view of a firm's core capabilities. The development of dynamic systemic relationship views per core capability, as well as between the different capabilities, stimulates ideas on the leveraging and bundling of core capabilities as value-added processes. Validating the relevance of the core capabilities is part of this process of developing "rich pictures" of the relationships between the different core capabilities.

- A firm's core capabilities have not all reached the same level of maturity. This implies that development activities related to human, structural and customer capital for those core capabilities that require further attention need to be initiated and monitored. The baseline information per capability as reflected in the Core Capability Framework is an important input in this operationalisation process. Project teams, with a mandate from the intellectual capital review board, focus on the ongoing implementation, development and leveraging of a firm's core capabilities and create momentum for operationalising the concepts by making them a practical reality. Learning groups of employees in self-organising networks that engage in dialogue, conflict and open testing of assumptions are vital for strategic success (Stacey, 1992).

- Growing intellectual capital through core capabilities is in essence a strategic activity. Strategic integration on an enterprise-wide level is achieved through the Strategic Architecture of the firm, which reflects the core capabilities the enterprise requires to achieve its strategic ideals. This strategic logic needs to be repeated on the next operating level in the firm - usually in the form of strategic business units (SBU's). Strategic integration on an SBU level implies answering the following questions:

- Which of the firm's core capabilities can make a direct contribution to the achievement of our strategic goals? This answer creates the basis for two further areas of investigation and integration.

- What strategic gap closing initiatives should we engage on to leverage these core capabilities to our benefit?

- What are the implications of these core capabilities from a human, structural and customer capital perspective?

These conversations in SBU's create the basis for local meaning to emerge and for self-organising processes (Stacey, 1992; Stacey, 2001; Wheatley \& Kellner-Rogers, 1996) to dynamically reinforce the envisaged and required changes related to the growth of intellectual capital by focusing on core capabilities.

The above elements represent the key constructs associated with the Operationalisation Framework. The final construct of the theoretical model is the "change enablement process".

Change Enablement Processes

The creation of movement and exchange between the above four key constructs (Intellectual Capital Framework, Strategic Architecture, Core Capability Architecture and
Operationalisation Framework) of the conceptual model for growing intellectual capital by focusing on core capabilities is dependent on a change enablement process.

The change enablement process perspective that supports the development of core capabilities from an intellectual capital view is based on a delicate blend of two different, but complementary, approaches to change:

- A systematic, well-planned and orderly change process for executing mainly pre-determined activities. This represents a logical, rational approach to change where the focus is on the achievement of set targets, primarily through the sequential execution of parts in a whole. This approach utilises the guidelines and action-steps as reflected by Beer and Nohria (2000), Kotter (1995), Kotter and Cohen (2002), Luecke (2003), and Schaffer and Thomson (1992).

- An organic, systemic change process based on self-organising principles where an organisation, as a system, evolves from one state of functioning to another (new) state. This is a natural process of change where the inherent forces and energies in a system are utilised to produce the required adaptation. The organisation is viewed as a complex adaptive system. The work of Stacey (1992; 2001), Wheatley (1994), and Wheatley and Kellner-Rogers (1996; 1998) informs this view of the change enablement process.

The following assumptions related to planned change, as identified by Schein (1988), create the context for the change enablement process to guide the development of core capabilities for a firm from an Intellectual Capital perspective:

- Change not only involves learning something new, but also unlearning something already existing. Some of the challenges that the change process should address are:

o The development of mindsets that is aligned with a knowledge-centric organisational paradigm where knowledge is the currency of the future; and

- The unlearning of toxic mental models associated with the industrial age and a mechanistic worldview. Stacey (1992: 21) confirms this need when he states that: Today most of us are trying to explain a messy, opportunistic global competition game using mental models that focus on order, stability, cohesion, consistency and equilibrium.

- No change will happen in the absence of a motivation to change. If such motivation to change does not already exist, the creation of that motivation is often the most difficult part of the change process. The Intellectual Capital Framework and the Strategic Architecture of a firm create the basis to define a desired future state that solicits natural tension when this is compared to the current reality. Systems will seek tension-releasing mechanisms to reduce the existing gap. Releasing this tension through gap-closing activities, aimed at the creation of a Core Capability Architecture and the associated operationalisation efforts, enable movement and change resulting in new strategic positions for a firm. This process requires a unique blend of both planned and self-organising change activities.

- Change involves attitudes, values and self-images. The unlearning of prevalent responses in these areas is initially inherently painful and threatening. The guidelines as reflected in the normative, strategic and operational perspective of the Intellectual Capital Framework, the Strategic Architecture, and the Core Capability Framework of the firm are all valuable sources of information to guide new behaviour. Information is the nutrient of selforganising systems and feeds the system (Wheatley \& Kellner-Rogers, 1996).

- Change is a multi-stage cycle that is negotiated per stage. The implementation of the conceptual model on growing intellectual capital by focusing on core capabilities in a firm is a multi-stage approach that facilitates the gradual entrenchment of the concepts and processes associated with the model. 
The purpose of the change enablement process is to create cognitive and emotional leverages that will enhance the potential of an organisation to successfully implement the conceptual model of this study.

In the next part of this article the relationships between the key constructs of the theoretical model is explored as well as the key assumptions, the boundaries and the propositions about the model.

\section{Relationships between Constructs (How)}

This part answers the question how are the constructs in the conceptual model related? The representation reflected in figure 1 is also relevant here.

The development of core capabilities from an Intellectual Capital perspective is an iterative process where the key constructs of the conceptual model dynamically relate to each other. This iterative flow of information forms and informs the content related to the key constructs of the model as the development process unfolds over time. This means that in the initial phases of application and population of the model, the content embodied in the constructs can change due to the emergence of new insights.

The primary relationships between the key constructs of the theoretical model are as follows:

- The Strategic Architecture creates the context for all the other architectures or frameworks in the theoretical model. The Strategic Architecture defines the boundaries and competitive space within which a firm wants to excel. This influences the type of capabilities the company requires. The Strategic Architecture also signals some clues on what the focus and contribution of these core capabilities should be.

- The Intellectual Capital Framework informs the description of the chosen core capabilities in the Core Capability Architecture through human, structural and customer indicators per core capability. This link ensures that the firm's core capabilities are viewed from an intellectual capital paradigm. This insight about the expanded meaning of the different core capabilities also informs the Core Capability Framework and the Strategic Architecture.

- The Core Capability Framework informs the operationalisation of the firm's core capabilities. The content as developed in the Core Capability Architecture is utilised as basis for the operationalisation process. As the operationalisation process progresses over time these insights as feedback loops can influence the descriptions and key concepts associated with the firm's core capabilities.

- A change enablement process supports and facilitates the creation of content, meaning and alignment on the key constructs of the theoretical model.

\section{Key Assumptions (Why)}

This part answers the question what are the underlying dynamics that justify the selection of the key constructs and their relationships? Assumptions represent statements related to the theoretical model whose certainty is either doubtful or not yet proven as a judgement of fact. Key assumptions will be highlighted to explain the rationale of the theoretical model.

The key assumptions related to the theoretical model on the development of core capabilities from an Intellectual Capital perspective are as follows:

- It is useful to conceptualise an organisation's core capabilities from an Intellectual Capital perspective.

- The intellectual capital paradigm is an appropriate mental model for the information age.

- The intellectual capital paradigm can be utilised as a perspective for informing management decision making on strategy for a firm. The Intellectual Capital Framework as a construct in the theoretical model with normative, strategic and operational elements represents the key aspects of the intellectual capital paradigm. It creates the basis for informing decisions on core capabilities in both the Strategic Architecture and the Core Capability Framework of the conceptual model.

- The Intellectual Capital Framework as presented in the conceptual model represents a relatively generic description of the concepts associated with the intellectual capital paradigm and is at least applicable to the financial services sector, given the context in which the model was developed.

- A strategic approach to the management of intellectual capital starts with a view on the core capabilities the business requires to achieve its strategic ideas and ideals.

- It is possible for the leadership of a firm to identify and select the appropriate core capabilities that will enhance and support the achievement of the firm's strategic intent. The Strategic Architecture of the firm creates a context for the deployment of the selected core capabilities.

- The intellectual capital school of thought creates the opportunity for identifying appropriate intellectual capital indicators for a firm's core capabilities. This intellectual capital view on core capabilities advances the basis of a useful and consistent taxonomy. An intellectual capital view generates multiple perspectives on a capability that are useful for the development, entrenchment, measurement and leveraging of core capabilities over time.

\section{Boundaries of the theory (Where)}

The boundaries of the theory specify the limits for application of the theoretical model and refer to temporal and contextual factors that influence the generalisability of the theory (Dubin, 1976; Whetton, 1989).

Some elements of the theoretical model for the development of core capabilities from an Intellectual Capital perspective as described in this article are context sensitive. The following constructs are specifically context dependent as indicated in figure 1 :

- Strategic Architecture.

- Organisational Core Capability Framework.

- Operationalisation Framework.

- Change enablement process.

The Intellectual Capital Framework as reflected in the theoretical model is visualised as being a relatively generic approach to intellectual capital and represents insights, models, metaphors, and measures appropriate for the information age and the new realities associated with knowledge economics.

The intent of the theoretical model is to provide guidance to companies on how to grow their intellectual capital by focusing on core capabilities. The model is a conceptual reference map for mobilising this strategic sensemaking process. It requires a unique application process for a firm, given the firm's history, strategy and readiness to embark on this journey.

\section{Propositions about the Model}

Propositions are logical deductions about the theoretical model and should be read in conjunction with the assumptions covered already.

The following ten propositions are logically consistent with the theoretical model as described:

- Intellectual capital is a multi-dimensional construct and consists of three inter-related elements: human, structural and customer capital. The cumulative and reinforcing effect contribute to the growth in the value of financial capital.

- The relationships between the above capitals imply that: - Human capital is not equal to intellectual capital.

- Human capital is the root cause for the growth of intellectual capital.

- Human capital is a necessary, but not sufficient condition to explain the cause and growth of intellectual capital.

- Human capital causes a change in the level of structural and customer capital in a firm. 
- Customers are the reason for the existence of a business from a customer-centric strategic positioning viewpoint. Customer capital growth is dependent on both human and structural capital, but accumulates and reflects unique value in the form of brand value, customer and other stakeholder relationships.

- The value of the intellectual capital of a firm is dependent on the available innovation capacity. Access to intellectual capital (owned and non-owned) increases the innovation potential of a firm, but is dependent on the image of the enterprise. Organisational image is informed by the financial performance of the firm and the reputation of leadership.

- The main drivers of intellectual capital from a strategic perspective are:

$\circ$ A positive organisational image.

- Clarity on the core capabilities a firm needs to achieve its strategic intent.

- A knowledge management capacity to enable knowledge flows related to human, structural, customer and financial capital.

- Innovation capacities supported by a performance culture and innovation structural capital in the form of a robust innovation funnel and process to extract and capture innovative ideas.

- Capabilities are organisational resources, practices and routines that are utilised in business processes to create value-added outputs for the business. Core capabilities represent strategically valuable tangible and intangible resources the business requires to achieve differentiation and competitive prosperity. The more a firm can combine these core capabilities in a value chain, the less imitable the products and services and the higher the differentiated strategic positioning and competitiveness of the company.

- Organisations can enlarge their strategic and operational understanding of core capabilities when they describe it from an Intellectual Capital perspective. This implies that the firm's core capabilities are described to reflect the appropriate human, structural and customer capital indicators. These intellectual capital indicators are future-orientated benchmarks per core capability of what will be visible over time if there is an increase in the value of the intellectual capital. This enables the measurement of change in the value of intellectual capital over time through the application of a consistent intellectual capital taxonomy.

- The Strategic Architecture of the firm influences the development of a position on the required core capabilities and intellectual capital indicators per capability. This means that the Strategic Architecture of a firm needs to be available as an input to the process to develop core capabilities from an intellectual capital view. A Dynamic Capability-Based strategy approach informs the firm's Strategic Architecture.

- The development of core capabilities by applying an intellectual paradigm is a long-term strategic process. A change management process is required to facilitate this journey in a firm.

- The growth of intellectual capital through core capabilities is dependent on the unique virtuous interaction of all the key components (Intellectual Capital Framework, Strategic Architecture, organisational Core Capability Framework, Operationalisation Framework and change enablement processes) of the theoretical model (figure 1).

\section{CONCLUSION}

In this two-part article series a conceptual model for the development of organisational core capabilities from an intellectual capital perspective has been described based on the guidelines of Dubin (1996), Mouton (2001) and Whetton (1989). An action research process was deployed to guide the emergence of the content of the model. The model consists of five key constructs:

- Intellectual Capital Framework.

- Strategic Architecture.

- Organisational Core Capability Framework.

- Operationalisation Framework.

- Change enablement processes.

The relationships between the constructs of the theory, key assumptions, boundaries and propositions of the conceptual model were described.

\section{REFERENCE}

Ackoff, R.L. (1993). From Mechanistic to Social Systemic Thinking. In L. Johnson (Eds.), Innovations in Management Series (1-12). Boston: Pegasus Communications.

Amit, R.H. \& Schoemaker, P.J.H. (1993). Strategic Assets and Organisational Rents. Strategic Management Journal, 14 (1): $33-46$.

Barney, J.B. (1991). Firm Resources and Sustained Competitive Advantage. Journal of Management, 17 (1): 99-120.

Beer, M. \& Nohria, N. (2000). Cracking the code of change. Harvard Business Review, 78 (3): 133-141.

Bontis, N. (1998). Intellectual Capital: An exploratory study that develops measures and models. Management Decision, 36 (2): 63-76.

Bontis, N. (1999). Managing organisational knowledge by diagnosing intellectual capital: Framing and advancing the state of the field. International Journal of Technology, 18 (5): 433-462.

Bontis, N., Dragonetti, N.C., Jacobsen, K. \& Roos, G. (1999). The Knowledge Toolbox: A Review of the Tools Available to Measure and Manage Intangible Resources. European Management Journal, 17 (4): 391-402.

Bontis, N. \& Fitz-enz, J. (2002). Intellectual capital ROI: a causal map of human capital antecedents and consequents. Journal of Intellectual Capital, 3 (3): 223-247.

Brennan, N. \& Connell, B. (2000). Intellectual capital: current issues and policy implications. Journal of Intellectual Capital 1 (3): 206-240.

Brookings, A. (1996). Intellectual capital: Core asset for the third millennium enterprise. New York: Thomas Business Press.

Collins. D.J. \& Montgomery, C.A. (1995). Competing on resources: strategy in the 1990's. Harvard Business Review, 73 (4): 118-128.

Davis, S. (1996). Future Perfect. Reading, Massachusetts: AddisonWesley.

Davis, S. \& Meyer, C. (1999). Blur - The Speed of change in the connected economy. New York: Warner Books.

Davis, S. \& Meyer, C. (2000). Future Wealth. Boston, MA: Harvard Business School Press.

Dawson, R. (2000). Knowledge capabilities as the focus of organisational development and strategy. Journal of Knowledge Management, 4 (4): 320-327.

Demarest, M. (1997). Understanding knowledge management. Long Range Planning, 30 (3): 374-384.

Dubin, R. (1976). Theory building in applied areas. In M.D. Dunnette (Ed.), Handbook of industrial and organisational psychology (17-39). New York: Wiley.

Edvinsson, L. (2002). Corporate Longitude. London: Prentice Hall.

Edvinsson, L. \& Malone, M.S. (1997). Intellectual Capital. London: Harper Business.

Elfring, T. \& Volberda, H.A. (2001a). Schools of Thought in Strategic Management: Fragmentation, Integration or Synthesis. In H.W. Volberda \& T. Elfring (Eds.), Rethinking Strategy (1-25). London: Sage Publications.

Elfring, T. \& Volberda, H.A. (2001b). Multiple futures of strategy synthesis: Shifting boundaries, Dynamic capabilities and Strategic configurations. In H.W. Volberda \& T. Elfring (Eds.) Rethinking Strategy (246-285). London: Sage Publications. 
Grant, R.M. (1991). The resource-based theory of competitive advantage: Implications for strategy formulation. California Management Review, 33 (3): 114-135.

Hamel, G. (1994). The Concept of Core Competence. In G. Hamel and A. Heene (Eds.), Competence based Competition (11-33). Chichester: John Wiley.

Hamel, G. (2000). Leading the revolution. Boston, MA: Harvard Business School Press.

Hamel, G. \& Prahalad, C.K. (1994). Competing for the Future. Boston, MA: Harvard Business School Press.

Harrison, S. \& Sullivan, P.H. (2000). Profiting from intellectual capital. Journal of Intellectual Capital, 1 (1): 33-46.

Harrison, S., Sullivan, P.H. \& Castagna, M.J. (2001). Intellectual capital best practices. In B. Lev, Intangibles. Management, Measurement and Reporting (155-165). Washington: Brooking Institution Press.

King, W.R. (1995). Creating a strategic capability architecture. Information Systems Management, 12 (1): 67-71.

Klein, D.A. (Eds.). (1998). The strategic management of intellectual capital. Boston: Butterworth-Heinemann.

Kotter, J.P. (1995). Leading change: Why transformation efforts fail. Harvard Business Review, 73 (2): 59-67.

Kotter, J.P. \& Cohen, D.S. (2002). The heart of change: Real-life stories of how people change their organisations. Boston, MA: Harvard Business School Publishing.

Lev, B. (2001). Intangibles. Management, Measurement and Reporting. Washington: Brooking Institution Press.

Long, C. \& Vickers-Koch, M. (1995). Using core capabilities to create competitive advantage. Organisational Dynamics, 24: 6-22.

Luecke, R. (2003). Managing change and transitions. Boston, MA: Harvard Business School Press.

Maynard, H.B. \& Mehrtens, S.E. (1996). The Fourth Wave. San Francisco: Berrett-Koehler Publishing.

Mouton, J. (2001). How to succeed in your Master's and Doctoral studies. Pretoria: Van Schaik Publisher.

Naisbitt, J. \& Aburdene, P. (1985). Re-inventing the Corporation. New York: Warner Books.

Prahalad, C.K. \& Hamel, G. (1990). The Core Competence of the Corporation. Harvard Business Review, 68:79-93.

Roos, G. \& Roos, J. (1997). Measuring your company's intellectual performance. Long Range Planning, 30 (3): 413426.

Roos, J., Roos, G. Dragonetti, N.C. \& Edvinsson, L. (1997). Intellectual Capital: Navigating the New Business Landscape. London: Macmillan Press.

Sanchez, R. (2001). Building Blocks for Strategy Theory: Resources, Dynamic Capabilities and Competences. In H.W.
Volberda \& T. Elfring (Eds.), Rethinking Strategy (143-157). London: Sage Publications.

Schaffer, R.H. \& Thomson, H.A. (1992). Successful change programs begin with results. Harvard Business Review, 70 (1): 80-89

Schein, E.H. (1988). Organizational Psychology, $3^{\text {rd }}$ ed. Englewood Cliffs, N.J.: Prentice-Hall.

Snowden, D.J. (2000). Liberating knowledge. In J. Reeves (Editor), Liberating knowledge (6-19). London: Caspian Publishing.

Snowden, D.J. (2002). Complex acts of knowing: Paradox and descriptive self-awareness. Journal of Knowledge Management, 6 (2) May.

Stacey, R. A. (1992). Managing the unknowable: Strategic boundaries between order and chaos in organisations. San Francisco: Jossey-Bass.

Stacey, R. A. (2001). Complex responsive processes in organisations. London: Routledge.

Stalk, G., Evans, P. \& Shulman, L. E. (1992). Competing on Capabilities: The new rules of Corporate Strategy. Harvard Business Review, 70 (2): $57-69$.

Stewart, T.A. (1997). Intellectual Capital. New York: Double Day.

Stewart, T. A. (2001). The wealth of knowledge. London: Nicholas Brealey.

Sullivan, P.H. (2000). Value-driven intellectual capital. How to convert intangible corporate assets into market value. New York: John Wiley.

Sveiby, K.E. (1997). The New Organisational Wealth. San Francisco: Berett-Koehler.

Teece, D.J., Pisano, G. \& Shuen, A. (1997). Dynamic capabilities and strategic management. Strategic Management Journal, 18 (7): 509-533.

Ungerer, M. (2004). Developing core capabilities in a financial services firm: An intellectual capital perspective. Unpublished doctoral thesis. Johannesburg, Rand Afrikaans University (RAU).

Wheatley, M. J. (1994). Leadership and the New Science. San Francisco: Berret-Koehler.

Wheatley, M.J. \& Kellner-Rogers, M. (1996). Self organisation: The irresistible future of organising. Strategy and Leadership, July-August: 18-24.

Wheatley, M.J. \& Kellner-Rogers, M. (1998). Bringing life to organisational change. Journal of Strategic Performance Management, April-May: 5-13.

Whetten, D.A. (1989). What constitutes a theoretical contribution? Academy of Management Review, 14 (4): 490-495. 